\title{
Blinding ocular trauma caused by remote controlled aerial drone
}

\author{
Haseeb Akram 두, Mohamed Seifelnasr 다 , Harry Roberts, James Myerscough
}

Ophthalmology, Southend University Hospital NHS Foundation Trust, Southend-OnSea, UK

\section{Correspondence to Dr Haseeb Akram; haseeb.akram5@gmail.com}

Accepted 25 March 2021
Check for updates

(c) BMJ Publishing Group Limited 2021. No commercial re-use. See rights and permissions. Published by BMJ.

\begin{tabular}{l}
\hline To cite: Akram H, \\
Seifelnasr M, Roberts H, \\
et al. BMJ Case Rep \\
2021;14:e242132. \\
doi:10.1136/bcr-2021- \\
242132 \\
\hline
\end{tabular}

\section{DESCRIPTION}

We describe a case of immediate and irreversible monocular blindness secondary to expulsion of the majority of uveal tissue due to penetrating eye injury by the rotating rotor blades of a remotecontrolled drone.

A middle-aged man presented to the eye clinic having been struck in the right eye a day before by his own drone.

Unaided visual acuity in the right eye (UAVA) was no perception of light (NPL). On examination, there was a horizontal corneoscleral full thickness laceration involving the upper one-third of the cornea crossing from limbus to limbus and extending to involve nasal and temporal sclera associated with uveal prolapse. There was no view of any intraocular structures due to dense haemophthalmos (figure 1). CT scan of the orbit confirmed a flat globe with loss of the crystalline lens.

Primary repair of open globe injury under general anaesthesia was conducted the same day. During the surgery (video 1 ), the extent of the wound was explored by blunt dissection under the conjunctiva. Necrotic uveal tissues were excised. The repair started by aligning the wound edges at the nasal and temporal corneal limbus with two $10 / 0$ nylon sutures followed by interrupted $8 / 0$ Vicryl sutures of the scleral laceration. The corneal wound was closed using 10/0 nylon. At the conclusion of the surgery, the conjunctiva was closed using $8 / 0$ Vicryl sutures with administration of subconjunctival betamethasone and cefuroxime.

Preservative-free levofloxacin six times/day, preservative-free dexamethasone $0.1 \%$ six times/ day and cyclopentolate $1 \%$ three times/day were given on discharge.

Throughout the postoperative recovery the integrity of the globe remained intact. The hyphaema gradually resolved over a few weeks. The globe remained chronically hypotonous with a persistent uveitis. UAVA never improved beyond NPL during the postoperative course and the patient had an afferent pupillary defect demonstrated by the contralateral pupil. By 12 weeks,
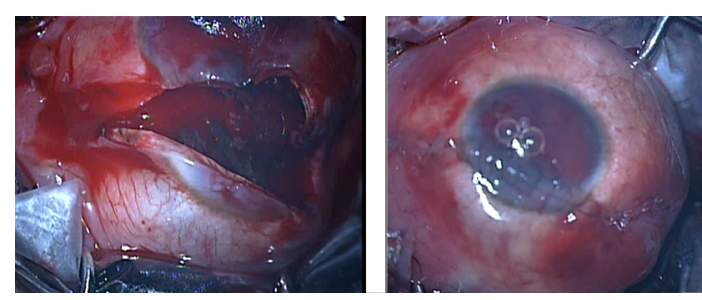

Figure 1 Preoperative (left) and immediate postoperative (right).

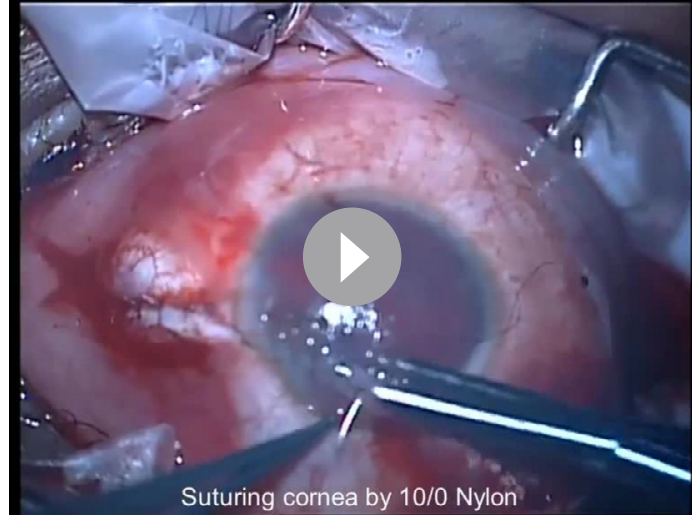

Video 1 Primary surgical repair of open globe injury.

the eye showed early signs of phthisis bulbi. No signs of sympathetic ophthalmia were seen in the healthy eye throughout follow-up and no further investigations were done for immunogenetic factors that may increase its risk. ${ }^{1}$ The patient was advised to use safety goggles in future for any possibly hazardous activity to protect the fellow eye.

Drones have become increasingly popular in the last decade. The Civil Aviation Authority (CAA) estimates that there are 130000 drone users in Britain (2019). ${ }^{2}$ To the authors' knowledge, this is the first case report of a drone-related open globe injury in the UK. A similar report has been discussed in a child in the USA which resulted in an estimated best corrected visual acuity of 6/120.

\section{Patient's perspective}

It was scary for me and although it was an accident, I wish I was more careful. If it can happen to me it can happen to anyone. The good thing is it can be avoided easily with a bit more awareness and some simple protective measures. I advise all fellow drone users to take precautions, especially younger people

\section{Learning points}

Personal protective equipment and care must be taken when using a drone. Users should be educated about the risks associated with drones.

- Despite prompt surgical repair of the open globe, the prognosis of such devastating injuries remains bleak from the onset. 
A drone is a remotely-controlled unmanned aircraft system designed for the consumer market. Currently in the UK they are regulated under The Drone and Model Aircraft Code of the CAA, requiring registration to be a user for all drones over $0.25 \mathrm{~kg}$ in weight and requires passing a theory test. ${ }^{3}$

An estimated 12842 hobbyist aircraft injuries presented to US emergency departments during 2010-2017 with 270 requiring admission. ${ }^{4}$

From a public health perspective, we hope this case report reminds the readers of the dangers associated with operating a drone without sufficient protection. We recommend the use of protective eyewear, for example, safety goggles and recovering the drone only once the propellers have completely stopped rotating. We would encourage the CAA to advocate or make mandatory the use of protective eyewear during the use of drones.

Contributors HA contributed to writing and submitting the case report. MSE performed surgery and provided images and video and edited case report. HR and $\mathrm{JM}$ contributed in writing case report and their support is appreciated.
Funding The authors have not declared a specific grant for this research from any funding agency in the public, commercial or not-for-profit sectors.

Competing interests None declared.

Patient consent for publication Obtained.

Provenance and peer review Not commissioned; externally peer reviewed.

\section{ORCID iDs}

Haseeb Akram http://orcid.org/0000-0002-1699-3313

Mohamed Seifelnasr http://orcid.org/0000-0001-9232-4923

\section{REFERENCES}

1 Chu XK, Chan C-C. Sympathetic ophthalmia: to the twenty-first century and beyond. J Ophthalmic Inflamm Infect 2013:3:49-9.

2 Moskowitz EE, Siegel-Richman YM, Hertner G, et al. Aerial drone misadventure: a novel case of trauma resulting in ocular globe rupture. Am J Ophthalmol Case Rep 2018;10:35-7.

3 The Drone and Model Aircraft Code. UK Civil Aviation Authority [Internet]. Available: https://register-drones.caa.co.uk/drone-code [Accessed 07 Mar 2021].

4 Johnson JA, Svach MR, Brown LH. Drone and other Hobbyist aircraft injuries seen in U.S. emergency departments, 2010-2017. Am J Prev Med 2019;57:826-9.

Copyright 2021 BMJ Publishing Group. All rights reserved. For permission to reuse any of this content visit

https://www.bmj.com/company/products-services/rights-and-licensing/permissions/

BMJ Case Report Fellows may re-use this article for personal use and teaching without any further permission.

Become a Fellow of BMJ Case Reports today and you can:

- Submit as many cases as you like

- Enjoy fast sympathetic peer review and rapid publication of accepted articles

- Access all the published articles

Re-use any of the published material for personal use and teaching without further permission

Customer Service

If you have any further queries about your subscription, please contact our customer services team on +44 (0) 2071111105 or via email at support@bmj.com.

Visit casereports.bmj.com for more articles like this and to become a Fellow 